\title{
Tingkat Pemanfaatan Koleksi Buku Digital Oleh Pemustaka di UPT Perpustakaan UIN Raden Fatah Palembang Tahun 2019-2020
}

\author{
Sarwita Pebriani ${ }^{1 *}$; Nor Huda Ali $^{2}$; Ahmad Wahidi ${ }^{3}$ \\ ${ }^{1}$ Fakultas Adab dan Humaniora UIN Raden Fatah Palembang \\ *Korespondensi: sarwitapebriani@ radenfatah.ac.id
}

\begin{abstract}
This research discusses the level of utilization of digital book collections by users at the UPT Library of UIN Raden Fatah Palembang in 2019-2020. The method used in this research is quantitative. Data collection techniques used are questionnaires (questionnaire), interviews, observation and documentation. The population in this study as many as 70 people with the technique used is purposive sampling. The results in this study indicate the level of utilization of digital book collections by users at UPT. The library of UIN Raden Fatah Palembang in 2019-2020 is high with the strengthening of existing data in the e-library system. Then for the suitability of digital book collections with readers, it can be categorized as sufficient to meet the needs of the users, even though there is still a lack of references in the digital bookcollection.
\end{abstract}

\section{Keywords: Utilization (e-books) College Libraries; Digital Book Collections; Library Users}

\begin{abstract}
Abstrak
Penelitian ini membahas tentang tingkat pemanfaatan koleksi buku digital oleh pemustaka di UPT Perpustakaan UIN Raden Fatah Palembang tahun 2019-2020. Metode yang digunakandalam penelitian ini adalah kuantitatif. Teknik penggumpulan data yang dilakukan yaitu menggunakan kuesioner (angket), wawancara, observasi dan dokumentasi. Populasi dalam penelitian ini sebanyak 70 orang dengan teknik yang digunakan yaitu purposive sampling. Hasil dalam penelitian ini menunjukan tingkat pemanfaatan koleksi buku digital oleh pemustaka di UPT. Perpustakaan UIN Raden Fatah Palembang tahun 2019-2020 adalah tinggi dengan diperkuat data yang ada pada sistem e-library. Kemudian untuk kesesuaian koleksi buku digital dengan pemustaka dapat dikategorikan cukup memenuhi kebutuhan pemustaka maskipun masih kurangnya referensi yang ada di dalam koleksi bukudigital.
\end{abstract}

Kata Kunci: Pemanfaatan (e-book) Perpustakaan Perguruan Tinggi; Koleksi Buku Digital; Pemustaka

\section{PENDAHULUAN}

Perpustakaan merupakan penyedia informasi dan pelestarian bahan pustaka yang berperan penting dalam bidang pendidikan, penelitian dan pengembangan ilmu pengetahuan maka di era globalisasi dibutuhkan perpustakaan digital dan teknologi informasi supaya pengguna perpustakaan tidak ketinggalan informasi (Sunu, 2014). Di era globalisasi ini, perkembangan informasi sangat mudah diperoleh, sumber ini memberi peluang untuk memberikan pelayanan informasi yang tingkatnya global, dengan terbukanya informasi pada tingkat global seseorang akan lebih mudah mendapatkan informasi dari penyedia jasa informasi (Hartono, 2016).

Perkembangan Ilmu Pengetahuan dan Teknologi (IPTEK) yang pesat secara tidak langsung berpengaruh pada dunia penelitian karena antara ilmu pengetahuan, teknologi, dan penelitian tidak dapat dipisahkan satu dengan lainnya. Kemajuan IPTEK dalam berbagai bidang tidak terlepas dari keberadaan institusi pendidikan yang dilengkapi dengan berbagai fasilitas pendukung, salah satunya adalah perpustakaan (Bachtiar, 2016).

Salah satu bentuk pemanfaatan teknologi sebagai media pembelajaran yaitu dengan memanfaatkan buku digital. Dulu, buku bisa baca dalam bentuk lembaran- lembaran kertas yang disusun sedemikian rupa sehingga bisa dibaca oleh kalangan masyarakat. Namun, sekarang seiring dengan kemajuan zaman, buku tidak hanya berbentuk kertas tapi bisa berbentuk digital yang bisa disimpan didalam komputer atau handphone canggih. 
Buku digital (Digital Book) adalah sebuah bentuk buku yang dapat dibuka secara elektronik melalui komputer, laptop, atau smartphone. Buku digital merupakan sebuah publikasi yang terdiri dari teks, gambar maupun suara dan dipublikasikan dalam bentuk digital yang dapat dibaca di komputer maupun alat elektronik lainnya. Buku digital atau e-book adalah salah satu teknologi yang memanfaatkan komputer yang digunakan untuk menampilkan informasi baik berupa teks, gambar, audio, video, maupun multimedia lainnya dalam bentuk yang ringkas dan dinamis yang dapat dibaca oleh komputer maupun perangkat elektronik lainnya (Ruddamayanti, 2019).

Berdasarkan Undang-undang No. 43 tahun 2007 tentang perpustakaan pada pasal 1 ayat 2 disebutkan bahwa koleksi perpustakaan merupakan semua informasi dalam bentuk karya tulis, karya cetak dan atau karya rekam dalam berbagai media yang mempunyai nilai pendidikan yang dihimpun, diolah dan dilayankan. Jadi koleksi digital merupakan koleksi perpustakaan atau materi arsip yang diubah (coverted) kedalam format yang terbacakan mesin dengan tujuan untuk pelestarian bahan pustaka atau untuk penyediaan akses secaraelektronik.

UPT Perpustakaan UIN Raden Fatah Palembang merupakan salah satu perpustakaan yang telah menyediakan koleksi buku digital untuk dimanfaatkan oleh pemustaka sejak 15 Agustus 2018, dimana aplikasi tersebut dapat diunduh di Playstore melalui smartphone bidang koleksi yang meliputi agama, bahasa dan sastra, ekonomi, filsafat, hukum, kesehatan, komputer, matematika dan sains, metodelogi penelitian, pendidikan, pertanian perkebunan, perternakan dan kelautan, psikologi, pustaka anak, seni, sosial, dll. dengan jumlah keseluruhan koleksi berjumlah 658, saat ini jumlah anggota dari e-library UIN Raden Fatah berjumlah 702 Anggota. Namun, saat ini masih ada pemustaka yang belum mengetahui adanya koleksi buku digital di UPT Perpustakaan UIN Raden Fatah Palembang, dan belum memiliki akses untuk login ke aplikasi tersebut. Sementara itu, dalam mengakses koleksi buku digital ini pemustaka yang sudah mendaftar sebagai anggota menunggu untuk dilakukanya proses aktifasi dari admin untuk selanjutnya dapat mengakses koleksi tersebut dan koleksi buku digital ini juga diperuntukkan secara online dan tidak secara offline hal ini mempengaruhi minat pemustaka dalam mengakses koleksi digital tersebut (Observasi Peneliti, 11 April 2020).

Kemajuan teknologi informasi membawa dampak besar bagi perpustakaan. Hal ini mendorong perpustakaan untuk selalu mengoptimalkan layanan informasi bagi pemustaka, sehingga di era globalisasi saat ini perpustakaan menawarkan suatu inovasi baru dalam memenuhi kebutuhan informasi bagi pemustaka dengan menyajikan koleksi yang semula dalam bentuk tercetak kini dapat dapat ditemui dalam bentuk digital. Oleh karena itu, diharapkan koleksi digital yang terhubung dengan internet dan dapat diunduh (download) dapat dimanfaatkan oleh pemustaka, tetapi sampai saat ini masih terdapat pemustaka yang belum mengetahui akan adanya koleksi buku digital tersebut, dan belum memiliki akses untuk login ke aplikasi $e$ - Library. Berdasarkan latar belakang permasalahan tersebut penulis tertarik untuk mengetahui lebih dalam lagi tentang "Tingkat pemanfaatan koleksi buku digital oleh pemustaka di UPT Perpustakaan UIN Raden Fatah Palembang".

\section{METODE PENELITIAN}

Jenis penelitian yang digunakan adalah pendekatan desriptif dengan tipe penelitian kuantitatif yaitu penelitian yang didalamnya berhubungan dengan data-data yang berbentuk numerik atau dapat dinyatakan. Penelitian kuantitatif adalah penelitian yang berhubungan dengan angka-angka. Dalam hal ini prosedur penelitiannya dideskripsikan secara tepat dan jelas (Hartinah, 2014).

Dalam penelitian ini yang menjadi populasi adalah seluruh anggota yang ada di dalam $e$ library UIN Raden Fatah yang saat ini berjumlah 702 pemustaka. Kemudian menurut Arikunto untuk teknik pengambilan sampel dalam penelitian ini adalah teknik purposive sampling. 
Purposive sampling adalah teknik penentuan dengan pertimbangan tertentu dengan pertimbangan sebagai berikut: (Arikunto, 2002)

1. Pemustaka UPT Perpustakaan UIN Raden FatahPalembang

2. Mahasiswa yang berada di lingkungan kampus UIN Raden Fatah Palembang

Alasan mengambil teknik purposive sampling karena menurut Arikunto "Apabila subjeknya kurang dari 100 orang lebih baik diambil semuanya, dan apabila jumlahnya lebih besar dapat diambil antara 10-15\% atau 20-25\% atau lebih" (Arikunto, 2002). Penelitian ini menggunakan $10 \%$ dari jumlah populasi $n=10 \%$ x $702=70$, karena sampel yang digunakan jumlahnya di atas 100 maka sampel pada penelitian ini sebanyak 70 responden. Kemudian, data diolah menggunakan SPSS versi 22.

\section{HASIL DAN PEMBAHASAN}

Hasil penelitian penulis yang berjudul Tingkat Pemanfaatan Koleksi Buku Digital oleh Pemustaka di UPT Perpustakaan UIN Raden Fatah Palembang tahun 2019-2020. Data yang penulis peroleh berdasarkan hasil observasi, wawancara, angket dan dokumentasi. Angket dalam penelitian ini penulis bagikan kepada pemustaka yang telah terdaftar menjadi anggota pada $e$ library sebanyak 70 orang, data tersebut penulis dapatkan dari hasil obeservasi penulis dengan pustakawan yang mengelola aplikasi tersebut.

Pengambilan data dilakukan dengan cara menyebarkan angket yang telah dibuat dengan 24 pernyataan yang berhubungan dengan tingkat pemanfaatan koleksi buku digital oleh pemustaka di UPT Perpustakaan UIN Raden Fatah Palembang tahun 2019-2020 dengan menggunakan teoriHandoko.

Berdasarkan data yang telah diolah, maka peneliti dapat menyimpulkan bahwa tingkat pemanfaatan koleksi buku digital oleh pemustaka di UPT Perpustakaan UIN Raden Fatah Palembang tahun 2019-2020:

1. Variabel kebutuhan memperoleh nilai rata-rata sebesar 3,68 dengan kategori tinggi karena berada pada interval 3,40 - 4,20. Jadi dapat disimpulkan bahwa koleksi buku digital sudah memenuhi kebutuhanpemustaka.

2. Variabel motif memperoleh nilai rata-rata sebesar 3,94 dengan kategori tinggi karena pada interval 3,40 - 4,20. Jadi dapat disimpulkan alasan pemustaka dalam mengakses koleksi buku digital tinggi. Hal ini dikarenakan fitur yang menarik, mudah dimengerti dan temu kembali yang mudah membuat pemustaka mengakases koleksitersebut,

3. Variabel minat memperoleh nilai rata-rata sebesar 3,74, dengan kategori tinggi karena berada pada interval 3,40 - 4,20. Jadi dapat disimpulkan ketertarikan pemustaka terhadap koleksi buku digital dikategorikan tinggi. Hal ini terjadi karena pemustaka lebih berminat mengakases koleksi buku digital dimasa pandemi untuk memenuhi kebutuhaninformasinya,

4. Variabel kelengkapan koleksi memperoleh nilai rata-rata sebesar 3,54 dengan kategori tinggi karena berada pada interval 3,40 - 4,20. Maka dapat disimpulkan kelengkapan koleksi yang terdapat pada koleksi buku digital cukup lengkap meskipun belum terlalu banyak referensi seperti koleksitercetak,

5. Variabel keterampilan pustakawan dalam melayani memperoleh nilai rata-rata sebesar 3,54 dengan ketegori tinggi karena berada pada interval 3,40 - 4,20. Jadi dapat disimpulkan pustakawan sudah melayani pemustaka denganbaik,

6. Variabel keterbatasan fasilitas memperoleh nilai rata-rata sebesar 3,09 dengan kategori sedang karena berada pada interval 2,60 - 3,40. Maka dapat disimpulkan fasilitas dalam menunjang akses koleksi buku digital sudah cukup memenuhi meskipun ada beberapa hal yang masih kurang seperti panduan pemakaian koleksi buku digital yang masih minim. 
Tabel.1 Tingkat Pembaca pada Koleksi Digital

\begin{tabular}{|l|l|l|}
\hline \multicolumn{1}{|c|}{ Sub Variabel } & \multicolumn{1}{|c|}{ Indikator } & \multicolumn{1}{|c|}{ Nilai } \\
\hline \multirow{3}{*}{ Faktor Internal } & Kebutuhan & 3,70 \\
\cline { 2 - 3 } & Minat & 3,94 \\
\cline { 2 - 3 } Faktor Eksternal & Motif & 3,73 \\
\hline \multirow{3}{*}{ Kelengkapan Koleksi } & 3,54 \\
\cline { 2 - 3 } & $\begin{array}{l}\text { Keterampilan Pustakawan } \\
\text { dalam melayani }\end{array}$ & 3,54 \\
\cline { 2 - 3 } & Keterbatasan Fasilitas & 3,09 \\
\hline
\end{tabular}

Sumber: Data Primer yang diolah

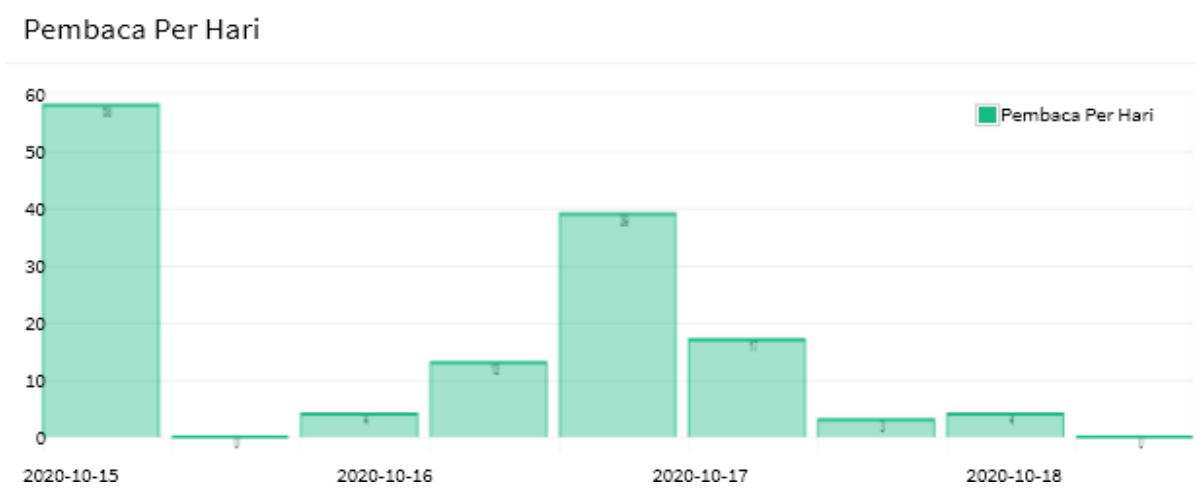

Grafik 1. Jumlah Pembaca (Sumber: Data Observasi)

Untuk analisis kesesuaian koleksi buku digital dengan kebutuhan pemustaka didasarkan pada hasil wawancara kepada dua responden secara daring (dalam jaringan). Peneliti mewawancarai Vindia Yuliansi (05 Oktober 2020, Pukul 10.00 WIB), salah satu pemustaka yang telah memanfaatkan koleksi buku digital sebagai berikut:

“.....Kalau menurut saya masih kurang, karena saat saya mencari buku yang saya inginkan terkadang tidak ada, alternatifnya saya mencari judul yang sedikit sama dari yang saya cari."

Selain itu, wawancara juga dilakukan bersama informan kedua yaitu Resya Pitria (25 Oktober 2020, Pukul 09.14 WIB) yang juga merupakan mahasiswa UIN Raden Fatah Palembang, sebagai berikut:

“..... Sejauh ini cukup memenuhi kebutuhan saya, walaupun referensi koleksi yang ada di e-library masih kurang dibandingkan dengan yang tercetak. Jadi sejauh ini dalam masa pandemi koleksi buku digital cukup membantu."

Berdasarakan informasi dari kedua responden tersebut terlihat, bahwa mereka memberikan respon yang cukup baik kepada koleksi buku digital meskipun masih belum banyaknya referensi koleksi yang ada di koleksi tersebut.

\section{SIMPULAN}

Berdasarkan hasil temuan dan analisis data dalam penelitian tingkat pemanfaatan koleksi buku digital oleh pemustaka di UPT Perpustakaan UIN Raden Fatah Palembang tahun 2019-2020, maka dapat disimpulkan sebagai berikut:

1. Tingkat pemanfaatan koleksi buku digital oleh pemustaka di UPT Perpustakaan UIN Raden Fatah Palembang tahun 2019-2020 dikategorikan tinggi. Hal ini dapat dilihat dari nilai rata-rata pada setiap sub variabel dan indikator yaitu rata-rata pada sub variabel kebutuhan sebesar 3,68. 
Sub variabel motif sebesar 3,94. Sub variabel minat sebesar 3,74. Sub variabel kelengkapan koleksi sebesar 3,54. Sub variabel keterampilan pustakawan dalam melayani sebesar 3,54. Sub variabel keterbatasan fasilitas sebesar 3,09 dan diperkuat dengan data yang ada pada sistem $e$ library. Dari hasil perolehan tersebut maka tingkat pemanfaatan koleksi buku digital oleh pemustaka di UPT Perpustakaan UIN Raden Fatah Palembang tahun 2019- 2020 tinggi untuk dimanfaatkan pemustaka yang ingin informasi secara cepat.

2. Koleksi buku digital yang ada di Perpustakaan UIN Raden Fatah Palembang dikategorikan sudah memenuhi kebutuhan informasi pemustaka dilihat dari hasil wawancara secara daring kepada dua responden. Berdasarakan informasi dari kedua responden tersebut terlihat, bahwa mereka memberikan respon yang cukup baik kepada koleksi buku digital mesikipun masih belum banyaknya referensi koleksi yang ada di koleksi tersebut

\section{DAFTAR PUSTAKA}

Arikunto, S. (2002). Metode Penelitian: Suatu Pendekatan Praktek (Edisi Revisi v). Jakarta: Rineka Cipta.

Bachtiar, L. (2016). Persepsi Mahasiswa Terhadap Penggunaan E-Book Dan E- Library: Studi Kasus Pada Science Direct. Jurnal Penelitian Dosen FIKOM, Vol 5, No 1.

Hartinah, S. (2014). Metode Penelitian Perpustakaan. Tanggerang Selatan: Universitas Terbuka.

Hartono. (2016). Manajemen Sumber Informasi Perpustakaan. Yogyakarta: Calpulis.

Ruddamayanti. (2019). Pemanfaatan Buku Digital Dalam Meningkatkan Minat Baca. Universitas PGRI Palembang.

Sunu, A. P. (2014). Peran Perpustakaan Digital Dan Teknologi Informasi Di Era Globalisasi. Jurnal Info Persada, Vol. 12, No. 1. 